CHAPTER TWENTY-THREE

\title{
THE FRENCH COLONIAL SCENE IN SOUTHEAST ASIA
}

Les Français sont incapables de créer des colonies prospères.

Quoted from critical Frenchmen by J. Wiselius (1878), p. 277

At the end of the 19th-century, the New Imperialists, USA and Japan, requested their share, and in Europe the recently formed German Empire aspired to have a colonial branch as well, while the Russian Empire tried to expand in the Far East. In the end the British Empire had to pay the largest price, the French a lesser one, but it played the game less well. The USA claimed the Philippines and, in fact, the whole of Central and South America as their hunting grounds; Japan claimed large parts of coastal China including Korea and Formosa; the European «scramble for Africa» divided up this continent, but was too expensive, came too late and did not provide a satisfying basis for the usual exploitation. The legitimation for these conquests was absent. The consequences of all this was a permanent threat of war in the world culminating in the First World War, exhausting all the classical European imperialists. ${ }^{1}$

Indeed, world imperialism at the end of the 19th-century also determined the fate of the exploitation of the colonies by means of opium. The new fundamental creed was: private profits had to be transformed into European state bureaucratic monopoly profits. The old opium import monopolies of most colonial governments (except for the English in India) combined with a private farming system were replaced by a "regiemethod". This made the state monopoly position complete. The only free trade in opium was called smuggling. This was paralleled by the warring states which now took the lead over private capital; that is to say, only

1 S. Halperin, p. 7, thirteen large wars were fought between and by colonial powers from 1870-1912 just in East Asia, as many as in the previous 70 years. I think that several French and Dutch conflicts in Southeast Asia are not considered. Still, they cannot alter the impression of the incredible aggressiveness of the Western powers also in this part of the world. 
private monopoly capital like the NHM in the Dutch East Indies could accommodate to this new situation.

This state had an image formed of European political thoughts, revived from the bourgeois onslaught on 'feudal' (aristocratic, monarchical and religious) aspirations and claims. The playground for these new aspirations became the colonies: the military repression and exploitation increased there tremendously. ${ }^{2}$

However, all this led to a very bloody flight and to a miserable end for the European powers. Within half a century the indigenous contra-powers like China, India or Indonesia were mobilized to such a degree that they could not be destroyed, and the "whites" had to flee. A few years later, around 1945, the game was in fact over.

Some could not believe or accept it, like the French and the Dutch. The total destruction of their colonial empires was necessary to teach them the new realities. In particular, the French were clearly the most stubborn colonizers of all. It took two long and devastating wars and the help of the USA before both definitely lost their position not only in Asia, but in the world at large. From triumphant winners in a long 19th-century, they transformed into "eternal losers" doped by what they first had sown in the colonies: the snake had bitten its own tail hard.

The French drug scene with its connections deep into the French navy reproduces most features of this decline-and-fall process: the Asian countries as resources for the foreign colonial government, which is the "source" of the military users and addicts, who brought "it" back to the homeland; there, the rich expatriates could be found in Le Moulin Rouge; the homeland in which the problem was settled through the opium den infrastructure and its deliverers; a new, politically compromised and socially criminal Western drug scene could develop in La Douce France; the colony itself stumbled into its last colonial drama performed in the mud of Dien Bien Phu (1954).

Because of its spectacular character and its most serious consequences for the world at large, a rich literature exists on this part of the opium history. First and foremost, there are the "bibles" of modern drug historiography, Alfred McCoy's The politics of Heroin in Southeast Asia or Carl Trocki's study about the Singapore scene, Opium and Empire. ${ }^{3}$ I have to confine

\footnotetext{
2 For this transformation see H. Derks (2008).

3 McCoy's study is now fully available on-line: see www.drugtext.org/library/books/ McCoy/default.htm.
} 
myself here to adding newer data here and there to try to give a sketch of the "French scene" in Southeast Asia, in Indochina and its wider context.

\section{The Beginning of a Disaster}

In 1800 the British and the French had already nearly two centuries of lethal Asian conflicts and mutual wars behind them. They were largely located in and around the Indian subcontinent. After they had recovered from the devastating Napoleonic European wars, they both started to move eastwards, gradually infiltrating Indochina and China. Not only in a military sense, but also in a cultural-religious way by sending missionaries who preached a strange, militant belief and sometimes the use of opium. In part 2 this kind of British (and American) assault on China was given globally.

On their way to the Chinese opium-Walhalla, the EIC's Bengal opium transports, those of the private "country traders" and many other transports of Arabs or Chinese had to pass the Straits. Some bridgeheads in Arakan (the later Burma) and coastal settlements were quickly constructed by the British. They, furthermore, had to deliver opium to their main client in the East Indies.

To ease this venture, Raffles occupied Singapore, which soon became the main naval and merchant base in Southeast Asia. After Napoleon's defeat, he could occupy the Dutch "possessions" in the East Indies as well. It could be used to negotiate with the Dutch, making them more or less loyal allies once the East Indies were returned to the Dutch with their new conquering plans.

For the French, from their point of view, there was not much territory left in Indochina. As losers of the large European wars, they were also much slower to take their share of this Indochina cake, although they started early enough. This was a remarkable and symptomatic beginning, and not only in hindsight. ${ }^{4}$

Here they had already relations with local rulers, while French missionaries spread the Catholic civilization française in the usual arrogant and aggressive way. It is one of the rare examples of Western missionaries arriving before the military occupation.

\footnotetext{
4 For the following see D. Hall, p. 461 ff., 608 ff.; N. Tarling in: Idem (ed.), vol. 2-1, p. 30-48. For the French in Laos I used M. Stuart-Fox.
} 
The military now could come, for example, in Vietnam to "protect" the Paris Foreign Missions Society. The Vietnamese elite saw these Catholic priests, obviously, as a cultural and political threat. King Minh-Mang, who succeeded to the throne in 1820 , hated these 'barbarians from the West'. Also, a most influential faction in the dynastic system, the courtesans, detested the priests as well because they preached monogamy.

Even after three French attempts, Minh-Mang remained unwilling to conclude a commercial treaty or even to receive a letter from the French king. He broke off all official relations with France. As a strict Confucian and admirer of the Chinese culture, he even started to persecute Christianity as had happened in an earlier period as well. The First Opium War of the British against China changed his mind, but he died soon thereafter, and his successor revived the policy of persecution with even greater vigour.

This Opium War was also a reason for France to change its Southeast Asian policies. Now it became as brutal as the British and sent a warship to Hué, which was coincidentally called the Héroine (1843). Next, they looked for some modus vivendi with the English and even battled in the Second Opium War alongside their greatest enemy. In this way, opium brought military peace and a peaceful competition between the Dutch, British and French only. Even with the first Western power in East Asia, Spain, the British made peace because they needed the Spanish silver to buy the Chinese products. ${ }^{5}$ Only the Americans had difficulties in participating in this Western concert (see ch. 28).

However, like the Dutch, the French were also left alone in their military adventures in Southeast Asia: they seized Saigon (Cochinchina) in 1862; a year later a protectorate over Cambodia was established, which gave them control of the lower Mekong. The expectation was that this river should bring the French right into the south of China, Yunnan. This was not confirmed by expeditions to the sources of the Mekong, and the interest shifted to the Red River. Hanoi was seized in 1873, Lao territory east of the Mekong followed, and ca. 1885 the whole of Vietnam including Tonkin was in their hands. The rest of Laos west of the Mekong and the western provinces of Cambodia surrendered to the French in the first years of the 2oth-century. Their main imperial challenge remained the largest country, Siam (the later Thailand). To achieve its goal, France used

5 For Anglo-Spanish projects at the time see N. Tarling in: Idem (ed.), vol. 2-1, p. 21 ff. 


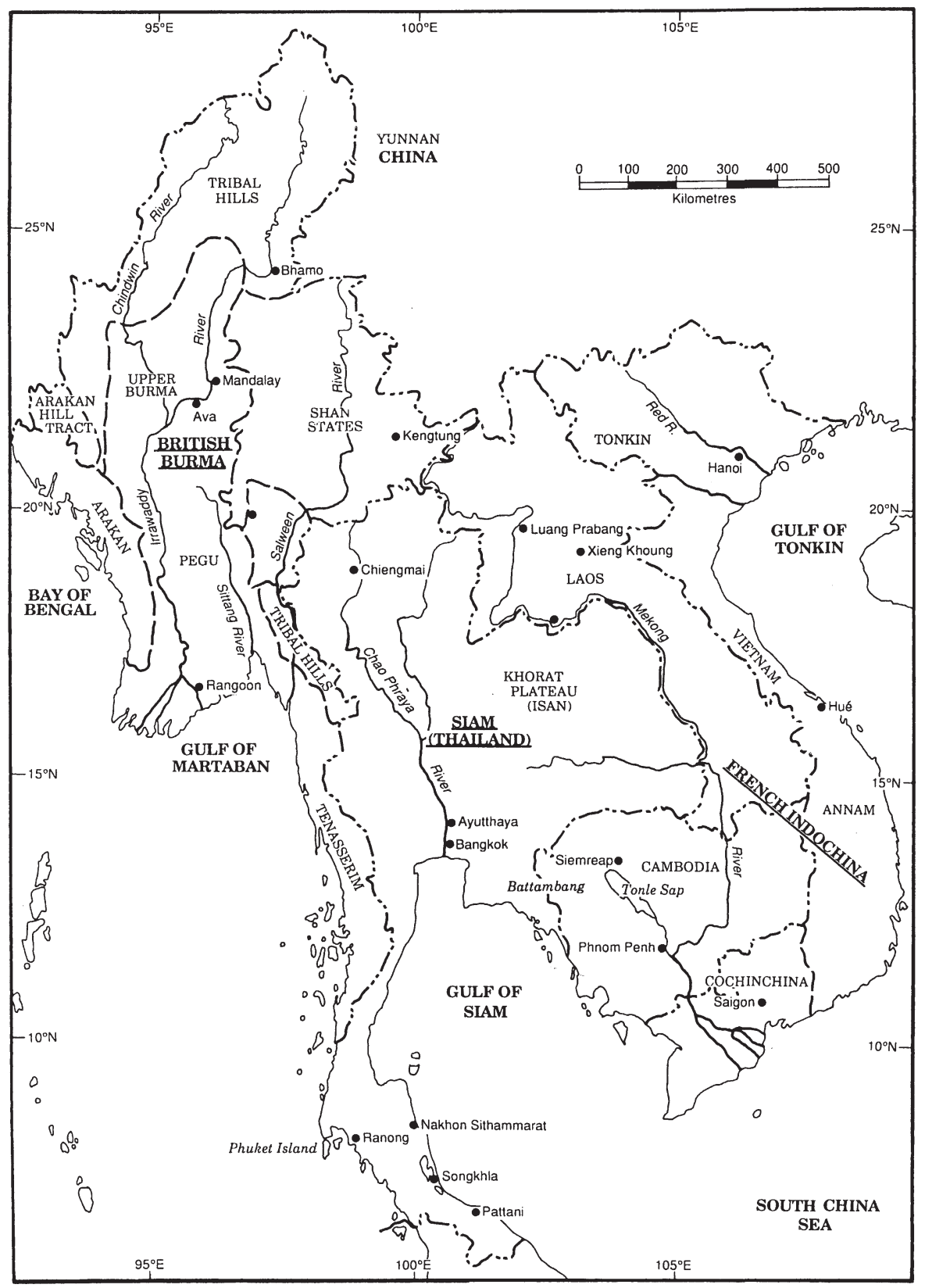

Map 11. Mainland Southeast Asia, 1880-1930

Source: N. Tarling, vol. 2-1, p. 78. 
old and flimsy Vietnamese claims to an Indochinese empire to ultimately create a casus belli for an intervention in Siam.

These military expeditions did not result in a reasonable basis for making colonies profitable from a Western point of view. Jacob Wiselius, a clever analyst of the Asian Western imperialism, gave a devastating view on the French inability to colonize wherever they landed in the world with their navies and military. In hindsight, he made a sound prediction. Wiselius asked himself whether the admiral who captured Saigon 'with exceptional good luck' in 1862 had the faintest idea that it meant a breach of peace among Annam, Siam and Cambodia and that in the near future the French weapons should be confronted with the whole of the militant Indochina'. ${ }^{6}$

After this quick overview we have to go back to basics: the opium business, established to pay for the French occupation of Indochina.

\section{The French Opium Performance}

Among the classical Western colonialists the French were the last to settle in this part of the world. Their opium performance was as dramatic as their political and military one. In our history the French must be held responsible for one of the most powerful and criminal drugs scenes in the present world. Let's start with a turning point in the whole development.

Their important and peaceful innovation in the opium scene is described as follows:

Of major importance were the gradual restriction and then rapid termination of revenue farming, especially the lucrative opium farms ... In Indochina between 1897 and 1904, the French established state monopolies on the sale of opium, alcohol and salt; this confirmed and at the same time centralized earlier and generally unsuccessful local French initiatives to abolish revenue farming, and greatly increased the weight of these consumption taxes so that they formed the major revenue item for the French colonial state. ${ }^{7}$

This transformation from revenue farming to centralized government monopoly in 1882 , became the model for all colonial powers. The "French general change" took place around 1900 everywhere in Southeast Asia. The legitimation was similar among all Europeans: we have to reorganize

\footnotetext{
6 J. Wiselius (1878), p. 285 .

7 The contribution of Robert Elson to N.Tarling in: Idem (ed.), vol. 2-1, p. 153.
} 
(= in this case: centralize) the whole opium production and distribution to minimize opium consumption as a concession to the many criticisms at home against the governments's opium business. And the factual motives everywhere for this transformation were, first and foremost, that the bureaucrats of the colonial state wanted the private profits of the mostly Chinese opium farmers for themselves. This was consequently accompanied by a general racism directed, this time, against the Chinese.

The motherlands ("metropolis"), furthermore, urged the colonies to look after themselves, but it also asked for an increased exploitation in order to pay for its own military expenses, which were incurred in the Far East as well. It this contradictory struggle of interests, the colonial bureaucrats normally won. Whatever was claimed about the dangers of opium, the immorality of this business, and so on, no influential officials with any authority cared much about the opium consumers, nor about the opinions in the motherlands. The best proof of this was the remarkable jump opium consumption made when the Opiumregies were installed.

\section{Revenue Farming 8}

In the 19th-century all Western colonies in Asia (as well as the independent kingdom of Siam) regulated their opium, as their single most important source of revenue, through a farm system:

The entire colonial enterprise in Southeast Asia was financed by revenue farms. Every colony, every state farmed out the bulk of its revenues to Chinese tax farmers. ... We cannot understand the nature of European colonialism in Southeast Asia without acknowledging the role of opium. ${ }^{9}$

States, colonies or state-private institutions like the VOC or EIC used the means of the highly lucrative revenue farming as explained in ch. 19. The alternative was a separate, substantial and expensive tax organization. In the case of the foreign occupiers, an additional disadvantage of this alternative was the provocative measures of the unpopular tax collectors among an indigenous population. Farms did not bear too close an examination. The European authorities, furthermore, could easily blame the Chinese for spreading and extending the opium vice against the many complaints from indigenous and later Western sides.

8 For the following see the contributions of Carl Trocki and Robert Elson in: N. Tarling (ed.), vol. 2-1, p. 85 ff., 147 ff. and in particular several contributions to J. Butcher, H. Dick (ed.). See also C. Trocki (2006), p. $28 \mathrm{ff}$.

9 C. Trocki (2006), p. 28. 
Revenues were drawn from many products and regulations, but everywhere the opium revenues were the most profitable ones for the states or colonies. The method used involved taxing exports of tin or rice, head tax on Chinese. In the Straits Settlements there were farms for alcohol, gambling, betel-nut, pork, pawnbroking and even markets. ${ }^{10}$

A well-known example: the opium and spirit farms for Singapore Island were the largest and most lucrative in British Malaya. ${ }^{11}$ They were led by the wealthiest and most powerful Chinese businessmen and regularly constituted between 40 and $60 \%$ of the entire state revenue. This was possible because in Singapore much more than elsewhere there was a commitment to free trade and a lack of taxable exports (see below).

The French understood the strategic importance of revenue farms as well. They started on a small scale collecting the money in Cochinchina. This was extended later to Cambodia and Annam-Tonkin but failed. Crawfurd wrote in 1820 :

The smallness of their numbers does not admit of the employment of instruments either sufficiently cheap, or sufficiently expert. They are but unwilling for and unequal to the task of bestowing the necessary attention to the minute details of a laborious business. ${ }^{12}$

They were largely unable to control their subordinates, who kept most of what they collected for themselves.

Crawfurd's opinion is that of the colonial administrator, of the foreign occupier, who ultimately had to rely (to his regret) on foreign help to collect money. The fact that they as European powers had to rely on Chinese help to get the "fruits of their repression" proved how weak their power was. It was the acknowledgment of this fundamental weakness which underlay the so-called indirect rule system of the English or the Dutch in the VOC period.

The institute of revenue farming was also well known in Europe. The reason for using these collectors was because the rulers who installed the people endowed with these "functions" trusted them. In Europe very often Jews were used as tax collectors, which realistically explained their unpopularity and their large capital sums. In this way a Jewish elite formed a tiny minority heavily dependent on the rulers who could also easily dismiss or eliminate them without much protest. Not for anti-

\footnotetext{
10 A. Foster (2000), p. 255 .

11 C. Trocki (1990), p. $96 \mathrm{ff}$. offers an overview of the opium farm annual rent from 1820-1882 with astonishing figures.

12 Quoted by J. Butcher, in: J. Butcher, H. Dick (ed.), p. 22.
} 
semitic, probably xenophobic reasons, but mainly due to jealousy of their accumulated wealth gained from the very unpopular dirty work for the "boss". 13

In Asia there were in fact not enough Jews available to do this kind of work. They had other things to do like the Sassoons: opium smuggling, banking, shipping between India and China. In Southeast Asia, however, there was a tiny Chinese elite available to do this job.

It is, in my view, not so much that 'European or Southeast Asian [political leaders] relied on revenue farming mainly because they could gain more income', as Butcher thinks, but to receive a regular income through taxing people instead of the normal colonial robbery by foreigners. ${ }^{14}$ Taxing is, furthermore, a prerogative of an accepted government. Like all colonizers, the French acted as if this was the case, but foreign colonial regimes were only feared and hated. The natives only collaborated within a socially or economically artificial framework.

How artificial it was becomes apparent from the fallacies French occupiers used to defend their distribution of the opium everybody knew to be pernicious. Even in this early phase of their Southeast Asian activities, complaints were made several times that they poisoned the indigenous people with their opium. The important official, Dussutour, replied:

A government which is ahead of the European civilization and which has a true providential mission in these countries cannot be itself the treacherous executioner (le bourreau empoisonné) of these peoples ... [it] is able to sell this task to others ... and close their eyes waiting for the period in which one could say: "it is enough" and put this announcement on all the borders of Cochinchina ...15

Along with this most cynical form of hypocrisy, there were also childish reactions to the complaints, claiming that distribution could not be stopped abruptly because of the health hazards like withdrawal symptoms. This moment occurred anyway in the next century when the French had to leave after the disaster of 1954. Others pointed to the high price of the opium and concluded that opium was only fit for the rich people of Amman and the Chinese. As elsewhere, the argument was also heard that only an overdose was bad, and the misery which followed was sketched in colorful details: but ... you had to be stupid to take an overdose.

\footnotetext{
13 H. Derks (2004), p. 160 ff.

14 J. Butcher in: J. Butcher, H. Dick (ed.), p. 23 (my italics. H.D.).

15 Quoted by C. Descours-Gatin, p. 39.
} 
The journal Le Courrier de Saigon (1oth of March 1864), official publication of the French administration, was also quite original when writing about the current annual budget: the morality of the French administration was proved beyond doubt since from the total of 3,012,000 French francs, $10 \%$ was spent to propagate the Christian faith and education among those poor opium addicts.

Despite these "arguments", there was almost no French supervision of the revenue farms, which were established around 1862. Therefore, the available data are not reliable, while the Chinese farmers' testimonies in the French part of their bookkeeping are described as outright falsification. ${ }^{16}$ Later Groeneveldt wrote how also the French bureaucrats were fraudulent. ${ }^{17}$

For about two decades the French were satisfied with their opium income. This was derived from several sources: from the tjandoe which was sold for about $\$ 1.8$ per thail; next, from the petals of the poppy flowers, called écorces. It had nearly no opium residue and was chewed by the poor people as a kind of sirih. Still in 1880 and 1881 a quantity of it of 176,683 and 104,346 thails was sold for $\$ 50,000$ and $\$ 30,000$, respectively.

One bought, furthermore, the dross from the pipes (tai amfioen) which was mixed with the tjandoe. The licenses to open an opium den produced another income of about $\$ 20,000$ a year. Finally, opium was exported to neighboring countries, but Groeneveldt could not discover how much.

In 1862 the revenue of the French colonial state was $\$ 61,334$, which increased four years later to $\$ 210,182$ and further to $\$ 465,000$ in 1873 . For the following years Groeneveldt summarized his findings in the next table.

This opium income in this period was always about $20 \%$ of the export earnings of rice, the main source of income. In 1874 an opium factory (bouillerie) had already been established in Cholon near Saigon.

However, Wiselius reproduces in his analysis of the French budgets in Cochinchina, etc. the 1877 budget of Cochinchina in full detail. The landrent brought in 3.5 million French francs ( $25 \%$ of the budget income) and as second main source was mentioned the 3.1 million francs $(22 \%)$ from the opium revenue farms. ${ }^{18}$ Why his contemporary, Groeneveldt,

16 W. Groeneveldt, p. $26 \mathrm{ff}$. It is a pity that Descours-Gatin did not know this detailed and reliable source about the opium economy and management in Cochinchina, Tonkin, Cambodia or Amman in the years to 1890.

17 Idem, p. 30.

$18 \mathrm{~J}$. Wiselius (1878), p. 74. There are as well 1.5 million francs in revenues from other farmings as there are arak, fisheries, birds' nests or the slaughtering of animals. 
Table 25. Opium sold to and Income from Revenue Farms in Cochinchina, 1874-1881 ${ }^{19}$

\begin{tabular}{lccc}
\hline Year & Opium sold in thails & \multicolumn{2}{c}{ Gross income from opium farms } \\
\cline { 3 - 4 } & & in \$-piaster & in French francs \\
\hline 1874 & 429320 & 972438 & 5348409 \\
1875 & 486953 & 949470 & 5222085 \\
1876 & 601975 & 1169772 & 6433746 \\
1877 & 699647 & 1337490 & 7356195 \\
1878 & 851080 & 1717603 & 9446817 \\
1879 & 837906 & 1603531 & 8819421 \\
1880 & 763605 & 1472093 & 8096512 \\
1881 & 710875 & 1332185 & 7327018 \\
\hline
\end{tabular}

came to a substantially different result only a few years later is not known: some difference between gross and net seems to be much too high; probably, it is a matter of fraudulent bureaucrats, about which he complained. ${ }^{20}$

Wiselius, a strong supporter of Western colonization, was rather critical about several French thoughts and practices experienced during his stay and travels in the colonies. ${ }^{21}$ First, he did not agree with the typical French direct rule through which all inhabitants are administratively transformed into 'Asian Frenchmen' with all the advantages of liberté, égalité et fraternité, of which they did not understand a syllable.

It would have been better, according to Wiselius, if the indigenous people were 'slowly prepared for freedom'! He displayed the most ideal-typical expression of the oikoidal principle when he proposes that, if a government of a state is formed in accordance with a people's need, one has to look at the organization of its households. In addition, he criticizes the enormous quantity of rules, regulations and standing orders issued: the indigenous people did not understand the need for this and did everything they could to negate them. He continues with:

It is not so much that we perceive it as a mistake of the state to subordinate the passions of the people to the treasury, but it is utterly wrong if the rules of the state do have a paradoxical character ... gambling is prohibited except on New Year's Day in Annam, and the sale of opium is forbidden as well. A few years ago-or probably still today-in Siam opium smokers had to have a Chinese tail and to pay six dollars a year for it. Whoever did not accept this was killed. The French government in Cochinchina, however, makes it easy for everybody to smoke opium for the annual price of 3.25

\footnotetext{
19 Idem, p. 27. The $\$=$ piaster $=5.5$ French francs.

20 C. Descours-Gatin, p. $27 \mathrm{ff}$. does not allow a solution in this matter.

${ }^{21} \mathrm{~J}$. Wiselius (1878), p. $108 \mathrm{ff}$.
} 
million francs, and through the establishment of numerous opium dens, it brings the habit even into the village households ... (the only effect of it is) ... that the savings of the indigenous people are spent on opium ... so that he has to build his hut even more primitively than his Javanese colleagues or his hut becomes more humid and unhealthy ...22

Those were the methods to force the Chinese to smoke opium.

\section{The Opiumregie}

The French invented this tradition, including its ambiguous background. The Dutch soon followed it in the East Indies, as was described in the previous part. Whatever the motives of the colonizers, an important aspect in all motherlands was that the colonies had to pay for themselves, and thus their exploitation had to be stepped up. This had to be realized in addition to the money, which had to be transmitted in standard form to the metropolis.

This also explains why the opium revenues strongly increased instead of diminishing through the Opiumregie, the military involvement of most colonial powers increased at the end of the 19th-century again, and an industrialization of the opium production was realized in many new opium factories. It is the period in which the euphemism "pacification" was used everywhere: in fact this word covered one of the most bloody periods in colonial history. ${ }^{23}$

The International Opium Commission (Shanghai, 1909) reported the following data in its typical way, as if all countries had fabulous statistical offices:

In $1906 \ldots$ opium provided $16.25 \%$ of the revenue in French Indochina, $29.02 \%$ in Hong Kong, $53.3 \%$ in the Straits Settlements, $10.8 \%$ in the Federated Malay States, $\mathbf{1 4 . 9 1} \%$ in the Netherlands East Indies, $14.3 \%$ in Formosa, $25.7 \%$ in Macao ..., and $15.55 \%$ in Siam. Burma, as a province of the Indian Empire, did not report separate figures. ${ }^{24}$

Still, they are impressive enough, in particular by suggesting how widespread opium use was in all those countries. The farmers had to pay more money in order to win the franchise, and they were eager to create as many consumers as possible, preferably addicts. The still well-known tricks among drug dealers were also used by them: selling cheaply or

22 Idem, p. 109.

23 See for the detailed overviews S. Halperin, p. $136 \mathrm{ff}$, appendices 2 and 3, p. 299-445; H. Derks (ed. 1989), passim.

24 A. Foster (2000), p. 256. 


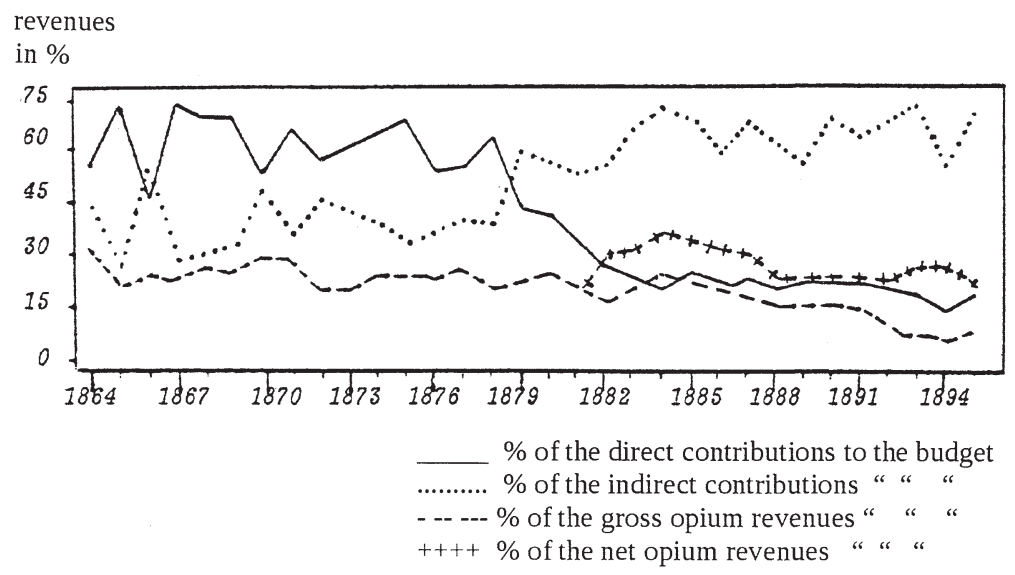

Figure 8. Percentage Gross and Net Opium Revenue in the French Colonial Budget of Cochinchina, 1864-1895.

Source: C. Descours-Gatin, p. 100, based on Budgets et comptes administratifs de Cochinchine, 1864-1895.

giving away opium to lure people into addiction. Critics in the West were also impressed by the figures quoted, knowing that without these revenues the colonies were difficult to finance, including the projects in the framework of the "mission civilisatrice". Reform of the farm system was, therefore, necessary, but not discontinuation.

There came, however, an end to this farming system, not so much out of compassion for the victims or international criticism, but for greed: it was decided that it would be better to collect the profits the farmers made. ${ }^{25}$ The colonial decision-makers had to finance the increasing military, administrative and luxury costs of the foreign settlers and their expatriates, i.e. their personal wealth: from the end of the 19th-century, one costly building after another arose everywhere for Western hotels, banks or government palaces; the whites built themselves large villa quarters with excessive gardens on the best spots.

The French were the first to transform the farm system into a centralized Opiumregie in 1882. That was a profitable move as the following table demonstrates.

25 C. Descours-Gatin. p. 90 ff. 
Table 26. Rentability of the Opiumregie compared to the Farm-system in Cochinchina, $1882-1885$ (in piaster) ${ }^{26}$

\begin{tabular}{llllrc}
\hline Year & $\begin{array}{l}\text { Gross income } \\
\text { Opiumregie }\end{array}$ & Total cost & Stock & $\begin{array}{l}\text { Net income } \\
\text { Opiumregie }\end{array}$ & $\begin{array}{l}\text { Advantage } \\
\text { compared with } \\
\text { farm-system of } \\
790684 \text { piaster }\end{array}$ \\
\hline 1882 & 1355657 & 605674 & +12034 & 734949 & -52705 \\
1883 & 1627736 & 622315 & +28719 & 976701 & +186047 \\
1884 & 2105704 & 780234 & -16730 & 1342200 & +551546 \\
1885 & 1868222 & 730375 & +19508 & 1118338 & +327684 \\
\hline
\end{tabular}

Table 27. Costs and Revenue of French Opiumregie in Cochinchina, 1882-1898 (x 1000 piaster* $)^{27}$

\begin{tabular}{|c|c|c|c|c|c|c|c|c|}
\hline \multirow[t]{2}{*}{ Year } & \multirow{2}{*}{$\begin{array}{l}\text { Gross } \\
\text { Income }\end{array}$} & \multicolumn{4}{|l|}{ Costs } & \multicolumn{3}{|c|}{ Profits } \\
\hline & & $\begin{array}{l}\text { Opium } \\
\text { buying }\end{array}$ & $\begin{array}{l}\text { Produc- } \\
\text { tion in } \\
\%\end{array}$ & $\begin{array}{l}\text { Person- } \\
\text { nel in } \\
\%\end{array}$ & $\begin{array}{l}\text { Building } \\
\text { etc. in } \\
\%\end{array}$ & $\begin{array}{l}\text { Total } \\
\text { costs }\end{array}$ & & $\begin{array}{l}\text { in } \% \text { of } \\
\text { gross } \\
\text { income }\end{array}$ \\
\hline 1882 & 1356 & 328 & 6 & 27 & 13 & 605 & 751 & 55 \\
\hline 1884 & 2106 & 537 & 8 & 19 & 4 & 780 & 1326 & 63 \\
\hline 1886 & 2015 & 553 & 8 & 22 & 4 & 836 & 1179 & 59 \\
\hline 1888 & 1855 & 412 & 10 & 28 & 4 & 704 & 1151 & 62 \\
\hline 1890 & 1653 & 344 & 8 & 34 & 2 & 606 & 1046 & 63 \\
\hline 1892 & 1815 & 814 & 8 & 19 & 2 & 1157 & 658 & 36 \\
\hline 1894 & 2686 & 1524 & 5 & 19 & 3 & 2098 & 588 & 22 \\
\hline 1896 & 2981 & 1218 & 4 & 28 & 2 & 1869 & 1112 & 37 \\
\hline 1898 & 4092 & 1003 & 6 & 32 & 6 & 1792 & 2300 & 56 \\
\hline $\begin{array}{l}\text { Total } \\
1882- \\
1898\end{array}$ & 37915 & 12420 & 7 & 26 & 4 & 19165 & 18750 & 50 \\
\hline- & - & --- & --- & - & --- & - & --- & - \\
\hline 1919 & 17981 & --- & - & - & - & 5133 & 12848 & 71 \\
\hline 1920 & 13321 & --- & - & --- & - & 2947 & 10374 & 78 \\
\hline 1921 & 15099 & --- & - & - & - & 4717 & 10382 & 69 \\
\hline 1922 & 17862 & --- & - & - & --- & 6190 & 11672 & 65 \\
\hline 1923 & 18332 & - & - & - & - & 6730 & 11602 & 63 \\
\hline 1924 & 14912 & - & - & - & - & 6429 & 8483 & 57 \\
\hline
\end{tabular}

* The Southeast Asian piaster refers to the Mexican dollar. Therefore, the indication is often with a \$ sign. One piaster is in this period valued at 5.55 French francs; until 1913 this is nearly equal to 1 US\$.

26 Idem, p. 110.

27 C. Descours-Gatin, p. 108; the figures for the years 1919-1924 are from T. Tong Joe, p. 92. The latter only gave gross and net income. For additional data on this period see Appendix 5 . 


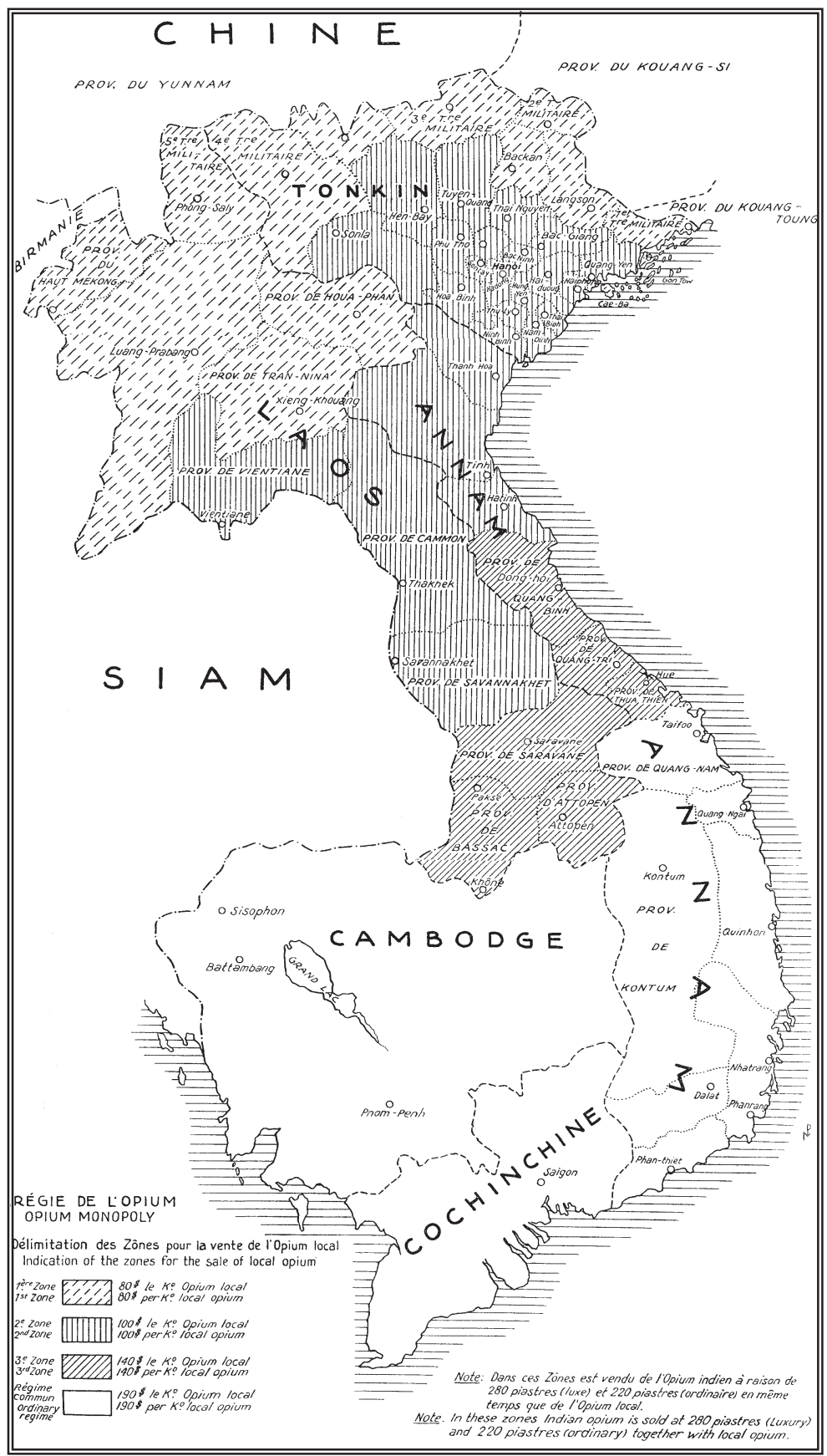

Map 12. Indochinese Zones with different prices of the French Opiumregie, ca. 1930

Source: Commission d'Enquête sur le Contrôle de l'Opium. League of Nations. In the East Indies the differences concern the bureaucratic measures, here they are related to prices. 
Added to this limited comparison, an overview of the opium purchases is given. From 1862 to 1882 they remained between 20,000 and 40,00o kg, but from 1882 they immediately doubled, tripled and soared sometimes to $170,000 \mathrm{~kg}$ around 1900 . Without any doubt: the Opiumregie was big business for the French compared with the farming system. Moreover, the quantities of opium started to flood Cochinchina in their search for new customers.

The French introduced the Opiumregie in Indochina in the early 1880 s, which was copied by the Dutch in "their" East Indies twenty years later as discussed above (ch. 19). The centralization of all parts of the process was finished when one opium factory for the whole of the French colonies was established in Saigon (1900). This modern factory was an extension of a previous plant, one which was operational already in the last years of the farm period (see Appendix 5).

In 1929 the opium revenue in French Indochina increased to nearly $\$ 8$ million for a much smaller quantity than earlier, i.e. 140,000 pounds. ${ }^{28}$

Immediately after the Second World War, the US pushed France to end its drug trafficking. In 1946 it looked as if the French were willing to take this hint. It took another five years, however, because the French dragged their feet on the issue. What followed is described thus:

In 1951 the Opium Purchasing Board ceased operations. Two years later France signed a United Nation protocol agreeing to end all state-sponsored trade in the drug. Though France was officially out of the opium business, unofficially it continued to trade in the drug. Two years before the Opium Purchasing Board officially closed its doors, the French Expeditionary Corps began buying opium from hill tribes throughout Indochina ... For a time (between 1949 and 1951) the Expeditionary Corps purchased only a fraction of the opium harvested by the Hmong. But the trade picked up substantially in 1951, when France's intelligence community took over the

28 Encyclopaedie, 1934 edition, p. 1258. T.Addens, p. 26 reproduces all sorts of League of Nations figures for the 1930s, but does not mention any production figures for French Indochina and the Dutch East Indies, where the cultivation and production of raw opium were largely confined to respectively Laos, the Meos countries and Java. He acknowledges that his figures for China are 'extremely inaccurate' and 'without doubt erroneous' (p. 28); the largest production of raw opium comes from India, Iran and other countries in 'Asia Minor' (mainly Turkey). T. Addens's doctoral dissertation is probably the most detailed exposé of the ecology, production, consumption and trade of raw and processed opium before 1940 (mainly the 1930s). About the health effects of smoking or eating prepared opium Addens supports Lyall's conclusion 'that a license to smoke opium is in truth a warrant authorizing a man to cut off a third of his life' (p. 83). At the same time he doubts this conclusion and also makes a case of proving that opium leads to less criminality than alcohol. This judgment must be based on a very narrow definition of criminality. 
operation and greatly expanded purchases of Hmong opium. The motive was not only to make money, but to deny the opium to the communists. ${ }^{29}$

Indeed, the French High Command financed its war against Ho Chi Minh's Viet Minh also through an extensive opium business. Thanks to this, the Hmong tribe, which delivered the stuff, became directly of strategic importance with all the consequences for its own later development (see below).

\section{The French Concession in Shanghai}

Thanks to their military cooperation with the English enemy in the Second Opium War, the French received a large part of the International Settlement in Shanghai in return. The growth of this city was fabulous after World War I. Between 1910 and 1930 the population almost tripled to three million. ${ }^{30}$ One-third of them lived in the International Settlement (nearly one million Chinese and 36,471 foreigners). In the French Concession (FC) there were 434,885 Chinese and 12,335 foreigners.

In particular, the FC was well-known for its exclusive and elaborate entertainment business which was mixed up with the narcotic scene in many ways. This life exploded after World War I. Overnight Shanghai became a cabaret town, a city of expensive nightclubs, brothels and the like. In 1915 in the International Settlement, there were officially about ten thousand prostitutes of all classes and nationalities with American and Russian ladies "at the top". Five years later the municipal authorities estimated this figure at 70,000 in the foreign concessions only. In the FC alone, there were 40,000 prostitutes.

Nearly all Chinese of any political creed believed that the enormous narcotic, gambling and prostitution industries of Shanghai

depended upon the protection of the consular system of extraterritoriality set up under the "unequal treaties" of the nineteenth-century ... even the most jaded urbanite had to be dismayed by the underworld's more violent manifestations in the form of kidnapping, robbery, and homicide committed by criminals who based themselves in the French Concession or International Settlement. ${ }^{31}$

\footnotetext{
29 K. Quincy, p. 85.

30 For the following see F. Wakeman, p. 9 ff.

31 Idem, p. 13 also for the following quotations.
} 
Observers stated that if anything socially unsound was discovered in the International Settlement it is immediately removed to the French Concession, where it comfortably settle down.' The FC became known as 'the dirtiest spot in the Orient'. Indeed, it had the largest opium dens, the biggest brothels, the fanciest casino's and the most brazen prostitutes and in the FC the police was 'doing nothing to stop this immoral traffic in contrast to other parts of the International Settlement'. The reason for this typical character of the FC is indicated by Chinese contemporaries as the consequence of the French laxity towards all their colonies: '... let the "natives" go to degradation and demoralization; their fate is no concern of the French nation.'

The corruption in the FC was endemic, also among French officials. Du Yuesheng, boss of the Green Gang, not only the main drugs-criminal that time in Shanghai but creator of one of the world's largest illicit cartels, was always intimately connected with "high politics" (see mainly ch. 31):

$[\mathrm{He}]$... was holding a series of conferences with the French authorities over gambling and opium ... had come to dominate the gambling and narcotics rackets in the French Concession under the protection of Chief Etienne Fiori and Consul General Koechlin ... the Green Gang boss had gotten the help of certain Cantonese investors and opened four gambling houses in the French Concession. ... Each gambling house quietly paid a daily protection bribe of $\$ 2,500$, which was discretely passed on to the highest authorities by Du Yuesheng himself. ${ }^{32}$

Du became a real Godfather. He was frequently requested by the rich of the FC to settle disputes arising over the division of inherited property, divorce and other personal problems; this gave him more reasons to enrich himself. More importantly, he was also the mediator in labor conflicts. This provided Du with the strike weapon in several labor unions of the FC.

"Paris" became embarrassed now the entire FC seemed to have been turned over to Chinese gangsters. ${ }^{33}$ From the French colonial government in Hanoi came the first complaints; press voices in the FC followed, and the FC police authorities answered first with "rounding up the usual suspects". That was not the end of this story: hostilities with Japan started in January 1932. A straightforward French admiral declared martial law in Shanghai and immediately prohibited gambling and drugs.

\footnotetext{
32 Idem, p. 201.

33 Idem, p. $202 \mathrm{ff}$.
} 
Du Yuesheng mobilized a thousand armed gangsters with tricolored armbands supplied by the French police, while rallying in support of the French Consul General Koechlin. The French navy cleared the streets in the FC of those dubious supporters of the French police: Du Yuesheng, Koechlin and Fiori had to resign.

The revenge of the first did not take long. A month later during a luncheon organized by Du, five high French officials were poisoned, of whom four died, including Koechlin. Fiori survived, though extremely ill, and left the FC to spend the rest of his lucrative opium life in a villa at Cagnessur-Mer. Large numbers of corrupt policemen in the FC were dismissed and replaced by disciplined people. The drug-related crimes now soared sky-high: they had increased in 1933 to six thousand, a year later the rate of eleven thousand was reached.

Probably because the poisoning "could not be proved", the new French leadership of the FC tried to negotiate with the Godfather: they were bribed or threatened with murder. Only one possibility to get rid of him remained: to provide him with attractive facilities outside the FC. Thus, negotiations were started with the Chinese municipality about what could be offered to Du.

There were a number of small factories - often only a single room just large enough to contain a laboratory-scattered around the French Concession where crude morphine manufactured in eastern Sichuan was refined into morphia and heroin by Chinese, Japanese, German and Russian chemists. If the Nationalist authorities, who had been trying once again in 1931 to establish a legal opium monopoly, could be persuaded to come to an agreement with Du Yuesheng, then these refineries might be relocated outside the French Concession in Greater Shanghai. ${ }^{34}$

So, the new French officials also played the game with the Godfather in exchange for Du's ability to prevent a strike of the French Tramway Union. How the Chiang Kai-shek part of the opium story developed will be dealt with in ch. 31. All this showed how deeply the French officials remained involved in criminal practices: sometimes as initiator, sometimes as profiteer, sometimes suffering from their own machinations.

During the Sun Yat-sen government the relationship with the Western occupation was already critical but generally of a polite character. That situation changed with his death in March 1925. Chinese opposition from all corners protested publicly against the foreign occupation in the International Settlement, against the centers of narcotics and Western

34 Idem, p. 205 . 
decadence, or against the Western or foreign labor exploitation. Strikes in foreign - owned industries became regular and time and again British, French marines or Japanese guards machine-gunned 'thousands of rioting coolies'35

After 1930 the influence of France and Britain in China faded away quickly, and the USA and Japan replaced them.

\section{The End of a Disaster}

Between June, 1940, and March 9, 1945, Japan enjoyed full control of Indochina with the compliance and assistance of the French colonial authorities. The colony was the main base for Japan's southward push against the Philippines and Southeast Asia after the attack on Pearl Harbor. ${ }^{36}$

This sentence contains the most serious allegation against the French possible: it is the betrayal of the Indochinese people, of their Western colleagues and their civilization. The latter fought the Japanese in the Pacific, Burma or the East Indies and succumbed to superior numbers. The betrayal of the Indochinese people was more direct: it concerned not only the collaboration with the enemy, but during the Japanese occupation, the French troops fought and suppressed the Indochinese resistance against the Japanese!

It is often shown that resistance movements against unpleasant regimes joined the new powers as liberators, the Germans in Europe or Japanese in Asia, hoping to obtain help in toppling that regime. The Flemish in Belgium; the Ukrainians in Russia; the Croatians in the Balkans; in India as well as in the Dutch West Indies, there was a pro-German movement; etc. They all supported the Germans or Japanese because they helped to expel the French, Soviets, Serbs, British or Dutch, respectively. Examples in Asia include the nationalists of Sukarno in Indonesia, certain Chinese warlords in China, or an Annamite monarchist movement in Indochina. This is rather understandable, although politically not very clever to collaborate with a much stronger warring party, and risking the exchange of one occupation for another.

However, I do not know of another example in which a former occupier collaborated with a new one. Certainly, also in Indochina there were individuals like General Catroux who rallied for De Gaulle and against the

\footnotetext{
35 J. Taylor, p. 49 ff.

36 H. Isaacs, p.156.
} 
dominant Vichy Fascists, but they were exceptions without an army or other support. ${ }^{37}$

This all ended in many actions by parties trying to save their skins or to take advantage of the existing chaos. For example: in the permanent power competition throughout Southeast Asia between the British and French, Siam remained largely unoccupied as a kind of buffer between the "European possessions". In 1939 it was renamed Thailand, and after 1945 it recaptured lost territory.

This was about three years before the English had to flee the realm and a decade before the French lost their last battle in Dien Bien Phu (1954). The Americans took over the colonial heritage, learned next to nothing from it, and had to leave Vietnam again two decades later in a chaotic flight with their tail between their legs. The result: a disillusioned American citizenship and dishonored military defeated by a small, selfconscious, poorly armed and rather weak, developing country.

Ho Chi Minh, the gravedigger of French and American imperialism in Asia, also destroyed their opium and heroin activities (see below). He had earlier singled out the French opium and alcohol monopolies as two of the definitive outrages of French colonialism. The Declaration of Independence of the First Vietnamese Republic (1945) accused the French of trying to 'enfeeble a Vietnamese race' through opium. The French must have perceived this as communist propaganda. However, Chantal Descours-Gatin confirmed this. ${ }^{38}$ Time and again this was repeated about the Dutch and British as well.

The French imperialism and colonialism were probably the most dishonorable and humiliating type from a Western point of view. After collaborating with the Japanese during World War II, France tried to restore its corrupt colonial power in a most provocative way (by breaking one promise after another) and in a highly cruel war against the Vietnamese resistance. This was formed in a struggle against the Japanese (and French) occupation and as the legitimate republican representative of the Vietnamese people. A lost affair practically by definition.

In Indochina the end came as the brilliant General Giap's forces were trained and ready, Mao Zedong had won in China (December 1949), and the American-guided Cold War had been initiated. Pierre Mendès-France told the French parliament that things had gone too far not to negotiate

37 R. Paxton, p. 80 ff. and passim. See also the contribution of David Marr in: A.McCoy (ed.,1980), p. 125-159.

38 C. Descours-Gatin. 
with Ho Chi Minh. For, he argued (October 1950) in a most remarkably dubious reasoning (and overdue):

It is the overall conception of our policy in Indochina which is wrong ... It is a fact that our forces ... are unable to bring about a military resolution, especially since the evolution of the Chinese situation, and it is a fact that our policy of making feeble concessions, and then withdrawing or denying them, has failed, and now, alas, will increasingly fail, to rally the mass of the Vietnamese people to our side. ${ }^{39}$

Their defeat in Vietnam was not the end of their controversial role in world politics as they continued their bloody repression in Africa (Algeria) and interventions in West African affairs or their dubious role in the Rwandan genocide (1990s).

39 Quoted in M. Shipway, p. 108. 